\title{
A high-resolution climate record spanning the past 17000 years recovered from Lake Ohau, South Island, New Zealand
}

\author{
Richard H. Levy ${ }^{1}$, Gavin B. Dunbar ${ }^{2}$, Marcus J. Vandergoes ${ }^{1}$, Jamie D. Howarth ${ }^{3}$, Tony Kingan ${ }^{4}$, \\ Alex R. Pyne ${ }^{2}$, Grant Brotherston ${ }^{4}$, Michael Clarke ${ }^{4}$, Bob Dagg ${ }^{5,6}$, Matthew Hill ${ }^{7}$, Evan Kenton ${ }^{5}$, \\ Steve Little ${ }^{5}$, Darcy Mandeno ${ }^{2}$, Chris $\mathrm{Moy}^{6}$, Philip Muldoon ${ }^{4}$, Patrick Doyle ${ }^{4}$, Conrad Raines ${ }^{4}$, \\ Peter Rutland $^{4}$, Delia Strong ${ }^{1}$, Marianna Terezow ${ }^{1}$, Leise Cochrane ${ }^{3}$, Remo Cossu ${ }^{8}$, Sean Fitzsimons ${ }^{9}$, \\ Fabio Florindo ${ }^{10}$, Alexander L. Forrest ${ }^{11}$, Andrew R. Gorman ${ }^{6}$, Darrell S. Kaufman ${ }^{12}$, Min Kyung Lee ${ }^{13}$, \\ Xun Li ${ }^{1}$, Pontus Lurcock ${ }^{10}$, Nicholas McKay ${ }^{12}$, Faye Nelson ${ }^{5,6}$, Jennifer Purdie ${ }^{14}$, Heidi A. Roop ${ }^{15}$, \\ S. Geoffrey Schladow ${ }^{11}$, Abha Sood ${ }^{16}$, Phaedra Upton ${ }^{1}$, Sharon L. Walker ${ }^{17}$, and Gary S. Wilson ${ }^{5}$ \\ ${ }^{1}$ GNS Science, Lower Hutt, 5040, New Zealand \\ ${ }^{2}$ Antarctic Research Centre, Victoria University of Wellington, Wellington, 6140, New Zealand \\ ${ }^{3}$ School of Geology, Environment and Earth Sciences, Victoria University of Wellington, \\ Wellington, 6140, New Zealand \\ ${ }^{4}$ Webster Drilling and Exploration Ltd, Porirua, 5240, New Zealand \\ ${ }^{5}$ Department of Marine Science, University of Otago, Dunedin, 9054, New Zealand \\ ${ }^{6}$ Department of Geology, University of Otago, Dunedin, 9054, New Zealand \\ ${ }^{7} 39$ Marine Parade, Macandrew Bay, Dunedin, New Zealand \\ ${ }^{8}$ School of Civil Engineering, The University of Queensland, St Lucia QLD, 4072, Australia \\ ${ }^{9}$ Department of Geography, University of Otago, Dunedin, 9054, New Zealand \\ ${ }^{10}$ Istituto Nazionale di Geofisica e Vulcanologia (INGV), 00143 Rome, Italy \\ ${ }^{11}$ Department of Civil and Environmental Engineering, University of California, Davis, CA 95616, USA \\ ${ }^{12}$ School of Earth Sciences and Environmental Sustainability, Northern Arizona University, AZ 86011, USA \\ ${ }^{13}$ Korea Polar Research Institute, Incheon, 21990, Korea \\ ${ }^{14}$ Meridian Energy, Twizel, 7901, New Zealand \\ ${ }^{15}$ Climate Impacts Group, University of Washington, Seattle, WA 98105, USA \\ ${ }^{16}$ National Institute of Water and Atmosphere, Wellington, 6021, New Zealand \\ ${ }^{17}$ Pacific Marine Environmental Laboratory, NOAA, Seattle, WA 98115, USA
}

Correspondence: Richard H. Levy (r.levy@gns.cri.nz)

Received: 4 December 2017 - Revised: 26 February 2018 - Accepted: 6 March 2018 - Published: 22 October 2018

Abstract. A new annually resolved sedimentary record of Southern Hemisphere mid-latitude hydroclimate was recovered from Lake Ohau, South Island, New Zealand, in March 2016. The Lake Ohau Climate History (LOCH) project acquired cores from two sites (LOCH-1 and -2) that preserve sequences of laminated mud that accumulated since the lake formed $\sim 17000$ years ago. Cores were recovered using a purpose-built barge and drilling system designed to recover soft sediment from thick sedimentary sequences in lake systems up to $150 \mathrm{~m}$ deep. This system can be transported in two to three $40 \mathrm{ft}$ long shipping containers and is suitable for use in a range of geographic locations. A comprehensive suite of data has been collected from the sedimentary sequence using state-of-the-art analytical equipment and techniques. These new observations of past environmental variability augment the historical instrumental record and are currently being integrated with regional climate and hydrological modelling studies to explore causes of variability in extreme/flood events over the past several millennia. 


\section{Introduction}

The Lake Ohau Climate History (LOCH) project is an international initiative involving scientists, engineers, drilling professionals, and students from New Zealand, Italy, Republic of Korea, United States of America, and Australia. Between 12 February and 5 March 2016 our drilling operations team completed a field expedition that recovered core from an $80 \mathrm{~m}$ thick sedimentary sequence of laminated mud that lies beneath the floor of Lake Ohau, South Island, New Zealand (Fig. 1). This sequence accumulated after glacial ice retreated from the lake basin approximately 17900 years ago (Putnam et al., 2013). Four holes at two sites (LOCH-1 and LOCH-2, Fig. 1) were drilled during this operation and a total of $229 \mathrm{~m}$ of sediment was recovered. This new sedimentary record offers a high-resolution (annual to decadal) climate record for the Southern Hemisphere. This progress report provides an overview of the scientific objectives of the LOCH project, summarizes drilling operations, highlights the new lake drilling capability that was developed and utilized for the project, and provides an update on the status of scientific work.

\subsection{Scientific rationale}

Inter-annual climate variability around New Zealand and the south-western Pacific is primarily driven by the position and intensity of Southern Hemisphere westerly winds (SWW) which are sensitive to changes in the Southern Annular Mode (SAM) (Ummenhofer and England, 2007; Ummenhofer et al., 2009; Wang and Cai, 2013), the influence of El NiñoSouthern Oscillation (ENSO) (Ummenhofer and England, 2007; Wang and Cai, 2013) and the Interdecadal Pacific Oscillation (IPO) (Folland et al., 2002; Salinger et al., 2001). These climate phenomena have a considerable influence on New Zealand rainfall, which is clearly illustrated by a reduction in South Island summer precipitation of up to $40 \%$ over the past 30 years in response to a trend towards a high positive phase of SAM (Ummenhofer et al., 2009). Concomitant southward migration and strengthening of the SWW have been driven by increasing atmospheric $\mathrm{CO}_{2}$ concentrations (Shindell and Schmidt, 2004) and ozone depletion (Thompson and Solomon, 2002). Leading hypotheses and modelling results suggest that the SWW will continue to shift south and intensify as climate warms (Toggweiler and Russell, 2008; Chang et al., 2012; Barnes and Polvani, 2013), with a significant impact on precipitation at the mid-latitudes of the Southern Hemisphere (Garreaud, 2007; Lim et al., 2016). However, our ability to interrogate these hypotheses and climate simulations with empirical data is limited by the relatively short duration of instrumental records. High-fidelity climate archives that span millennia, including intervals of past warmth, are required to place current anthropogenic climate change into a longer-term perspective and allow a more

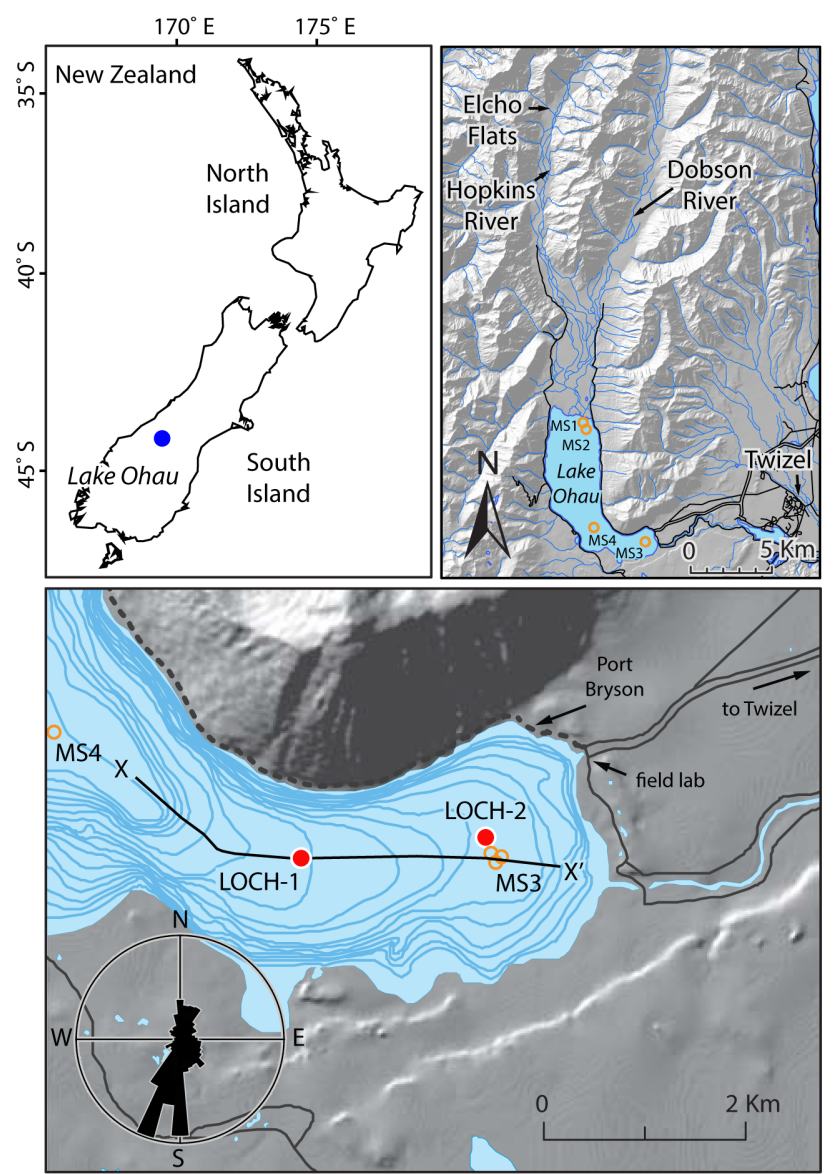

Figure 1. Location of Lake Ohau, South Island, New Zealand. Orange circles: monitoring sites $1-4$; red dots: $\mathrm{LOCH}$ drill sites; line $\mathrm{X}-\mathrm{X}^{\prime}$ : location of the seismic line illustrated in Fig. 3. Gravel access road indicated by the dashed line in the bottom panel. The rose diagram shows that the dominant wind direction is from the northnorth-east.

robust assessment of climate dynamics at the southern midlatitudes.

The Lake Ohau basin $\left(44^{\circ} 10^{\prime} \mathrm{S}, 169^{\circ} 49^{\prime} \mathrm{E}\right)$ contains a thick sedimentary sequence that accumulated following glacial retreat that began 17900 years before present (BP) (Schaefer et al., 2006; Barrell et al., 2011; Putnam et al., 2013). The study area is located at the northern boundary of the westerly wind belt and offers a unique location to examine the hydrologic response to changes in the SWW. Moorings fitted with instruments to measure currents, turbidity, and water temperature have been deployed in the lake since 2012. Data obtained from these instruments have been integrated with local weather station data, outflow measurements, and sediment trap data. Results show that sediment transport and deposition in the lake reflect seasonal variations in regional hydroclimate (Roop et al., 2015a, b). The $6 \mathrm{~m}$ long cores that were recovered from beneath the lake 
Line scan RGB

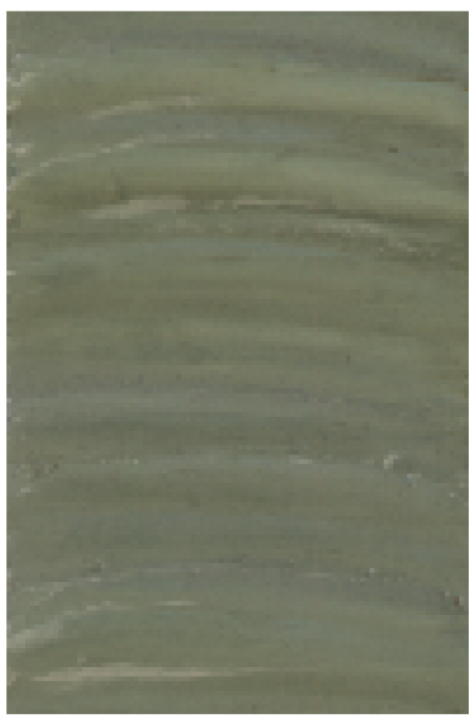

\section{Thin section}

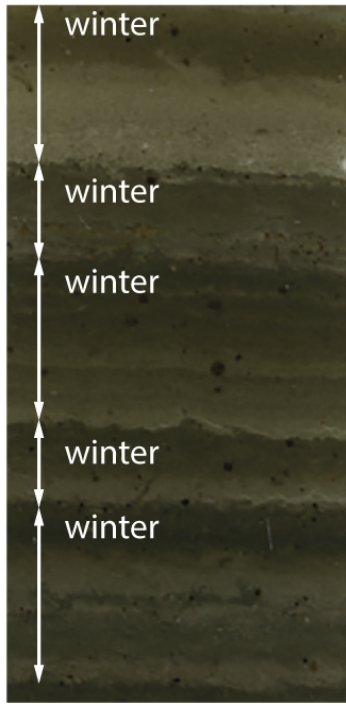

Figure 2. Line scan image from a $6 \mathrm{~m}$ long Mackereth core recovered from the sedimentary section near site MS-3. A petrographic thin section from the same core highlights sedimentary couplets that include lighter (summer) and dark (winter) layers.

bed near LOCH-2 (Fig. 1) using a Mackereth coring system (Mackereth, 1958) revealed a sedimentary sequence comprising mm-scale couplets of light and dark layers (Fig. 2). A detailed chronology for this sequence has been established by combining well-defined ${ }^{137} \mathrm{Cs}$ and ${ }^{210} \mathrm{~Pb}$ profiles, layer counts, and ${ }^{14} \mathrm{C}$ dates (Roop et al., 2015a; Vandergoes et al., 2018). The age model allows us to correlate the sedimentary sequence with hydroclimate data and shows that sedimentary couplets exhibit strong correspondence with lake inflow and outflow. Specifically, deposition of thin dense layers that are composed of the finest particle fraction occurs during winter. Less dense coarser layers are deposited during spring and summer and are generally thicker than the winter layers (Roop et al., 2015a). Measured annual outflow from Lake Ohau correlates with annual precipitation measured over most of the South Island (Ummenhofer and England, 2007). These data suggest that the package of sediment preserved beneath Lake Ohau offers an unprecedented opportunity to reconstruct South Island hydrology at annual timescales over the Holocene and at high resolution since the LGM. This record is of major global significance as similar high-resolution paleoclimate data series are exceptionally rare at the Southern Hemisphere mid-latitudes.

\subsection{Regional setting}

Lake Ohau occupies an intermontane basin that formed as ice advanced across the Mackenzie Basin during Late Quaternary glaciations (Golledge et al., 2012; Putnam et al., 2011, 2013). Terminal glacial moraines were deposited at the southernmost end of the basin 17900 years ago and form a natural dam (see Fig. 11 in Putnam et al., 2013). Today, the lake is fed by the Dobson and Hopkins rivers, which flow from the continental divide, draining a combined area of $924 \mathrm{~km}^{2}$, and converging just upstream of the lake delta. These two rivers contribute $\sim 85 \%$ of the total annual inflow (Woods et al., 2006). The lake has a mean depth of $74 \mathrm{~m}$ and reaches $129 \mathrm{~m}$ at its deepest point (Irwin, 1978). Water levels typically fluctuate by $<0.3 \mathrm{~m}$ throughout the year and are controlled via hydroelectric power infrastructure that was built in the 1970s and comprises a control gate and weir that cut the terminal moraine. Prior to construction, lake levels varied naturally by $\sim 0.5 \mathrm{~m}$, as determined by near-daily measurements dating to 1926 .

Lake Ohau sits at the northern edge of the westerly wind system that dominates zonal air flow at the southern midlatitudes. The north-south alignment of the Hopkins and Dobson valleys means the predominant wind flow over the lake is from the north, with a secondary south easterly mode. The highest wind speeds (up to $160 \mathrm{~km} \mathrm{~h}^{-1}$ ) come from the north and occur most frequently in spring and early summer when the westerly wind belt is located at its northernmost extent. During this period gusts over $100 \mathrm{~km} \mathrm{~h}^{-1}$ are common. There is a marked diurnal wind cycle in summer, with the calmest conditions in the morning and windiest in the late afternoon. Air temperature around the lake margin ranges between a winter mean of $6.2^{\circ} \mathrm{C}$, although it frequently drops below freezing at night, and summer mean of $14.3^{\circ} \mathrm{C}$ and decrease at a rate of $\sim 0.5^{\circ} \mathrm{C} / 100 \mathrm{~m}$ increase in elevation. Mean rainfall increases from $\sim 640 \mathrm{~mm}^{-1} \mathrm{ear}^{-1}$ at Twizel (elevation $470 \mathrm{~m}$ ) to over $2800 \mathrm{~mm}^{-1} \mathrm{rar}^{-1}$ at Elcho flats (elevation $739 \mathrm{~m}$ ) in the Hopkins Valley (Fig. 1).

\subsection{Lake hydrodynamics}

We initiated a hydrologic monitoring programme in 2009 that was expanded in 2012 to examine the physical processes that influence lake sedimentation and to help identify an optimal location to recover a long climate record. Moorings with temperature loggers and turbidity meters were deployed at monitoring sites (MS) -1 and -2 near the large delta at the northern end of the lake and MS-3 at the distal end of the lake (Fig. 1). Water current velocity data were collected at the delta between January 2012 and January 2013 using a RDI $1200 \mathrm{kHz}$, four-beam acoustic Doppler current profiler (ADCP) moored on the lake bottom at a depth of $25 \mathrm{~m}$ (Fig. 1, MS-1) and a RDI $600 \mathrm{kHz}$, four-beam ADCP at depth of $50 \mathrm{~m}$ (Fig. 1, MS-2). These instruments captured a series of major summer inflow events that occurred between $31 \mathrm{De}-$ cember 2012 and 15 January 2013, during which period one of the instruments was lost (Cossu et al., 2016). A Sontek $250 \mathrm{kHz}$ ADCP was deployed in September 2013 in the central basin in $129 \mathrm{~m}$ of water (Fig. 1, MS-4). This instrument samples water velocity and signal amplitude ( $\sim$ particle concentration) over the entire water column in $2 \mathrm{~m}$ depth incre- 


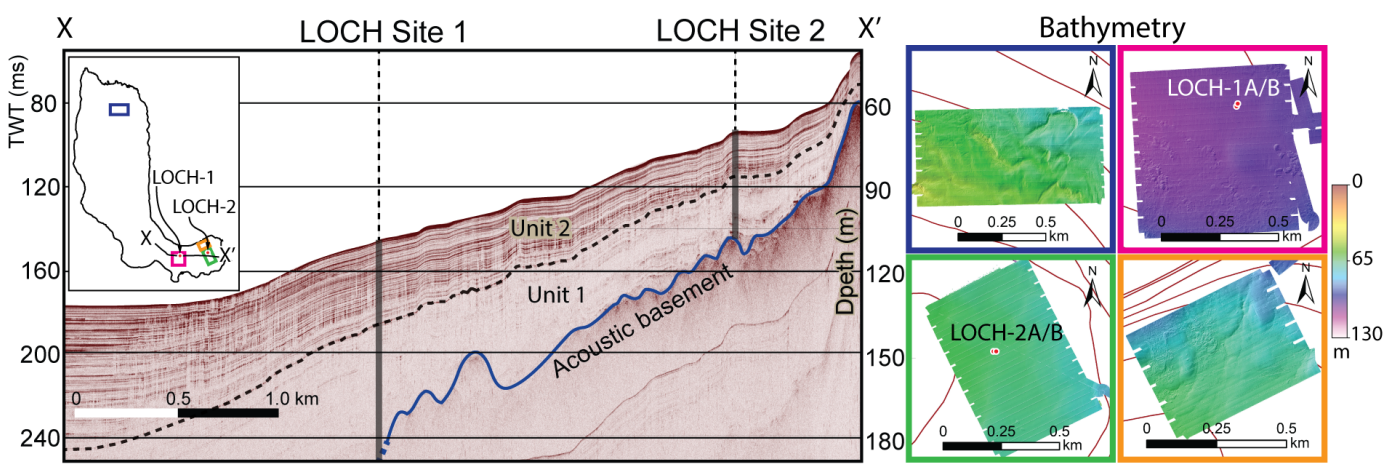

Figure 3. Seismic (boomer) reflection profile and sonar data from Lake Ohau showing the progressive thickening of the post-glacial sequence toward the central lake basin. The inset map shows the location of profile $\mathrm{X}-\mathrm{X}^{\prime}, \mathrm{LOCH}$ drill sites (red dots), and bathymetric surveys (coloured squares correspond to data shown at the right of the figure).

ments. Several types of sediment trap have been deployed over the monitoring period, including simple centrifuge tubes attached at discrete intervals along mooring lines at MS-1, 2, and -3 (Fig. 1), a $46 \mathrm{~cm}$ diameter single cone trap (first deployed in May 2009), and a NiGK Corporation SMD-13S6000 carousel trap system with a $36 \mathrm{~cm}$ diameter cone and set up with fortnightly rotations of sample bottles (first deployed in August 2014). Both large sediment traps are located at MS-3 near the distal end of the lake in $68 \mathrm{~m}$ of water (Fig. 1).

Results of this monitoring programme indicate that Lake Ohau is isothermal in winter when water column temperature decreases to $\sim 8^{\circ} \mathrm{C}$. The lake becomes thermally stratified in November and surface temperatures reach maximum values of $\sim 18{ }^{\circ} \mathrm{C}$ between January and March. Large inflow events $\left(Q \geq 500 \mathrm{~m}^{3} \mathrm{~s}^{-1}\right)$ that follow strong summer rainstorms trigger high-concentration turbidity currents, which are the main agents for sediment delivery and deposition. During winter, smaller turbidity currents also occur after rain events but typically flow along the lake bottom as the temperature of the inflowing river water is below that of the lake. A conceptual hydrologic sedimentation model was developed from regional climatic and monitoring data (Cossu et al., 2016). In this model, hydrodynamic processes, which are primarily controlled by changes in lake temperature, produce the seasonal signal that is preserved in sediments at the distal end of the lake. Inflow events between late spring and early autumn generally transport sediment in interflows and disperse clastic particles across the entire lake basin. In contrast, cold, dense winter inflow events generally plunge and flow across the basin near the floor of the lake. These bottom flows cannot carry sand-sized sediment into shallower regions at the distal end of the lake. Fine grained silt and clay that remain suspended from spring to autumn inflow events settle out at the distal end of the lake during winter. This seasonal contrast produces a distinct winter layer of very fine silt (Fig. 2). In contrast, sediment layers at the delta and central basin record a complex event stratigraphy, including dm thick sandy turbidites.

\section{Drill site selection and characterization}

\subsection{Acoustic surveys}

Sub-bottom profile (3.5 kHz "Chirp") and high-resolution seismic reflection (boomer) data were collected during several surveys between 2011 and 2015. The seismic sequence (Fig. 3) is characterized by an acoustically opaque unit with an undulating surface (acoustic basement) that is overlain by a unit with indistinct parallel reflections (Seismic Unit 1) and a unit with strong parallel reflections (Seismic Unit 2). Reflections in Seismic Unit 2 can be traced across the basin and acoustic layers thicken toward the centre of the basin where the total post-glacial sequence is at least $150 \mathrm{~m}$ thick. We inferred that the basal unit (acoustic basement) was composed of diamicton deposited as glacial moraine and sub-glacial till that accumulated as ice last retreated from the lake basin. In contrast, the layered sequences (Seismic Units 1 and 2) accumulated once the lake had formed. Seismic Unit 1 was initially interpreted as a sequence of proglacial sediments and homogeneous muds that accumulated during glacial retreat. Seismic Unit 2 was interpreted as a Holocene sequence of well-stratified, laminated sedimentary couplets which represented a continuation of the stratigraphy observed in short cores recovered from the upper $6 \mathrm{~m}$ of sediment fill. A highfrequency bathymetric sonar and side scan survey was conducted over targeted regions across the delta system and at the distal end of the lake using a Geoswath Plus $500 \mathrm{kHz}$ phase-measuring bathymetric sonar mounted on a Teledyne Gavia autonomous underwater vehicle. Measurements collected from this untethered vehicle produce bathymetry with better than $20 \mathrm{~cm}$ spatial resolution that reveals the subaqueous geomorphology of the lake floor in exceptional detail. In total eight $\sim 1 \times 1 \mathrm{~km}$ grids were surveyed around the lake from the inflow at the northern end to the outflow weir at 
the southern end (Fig. 3). These data demonstrated a wide range of geomorphic features within the lake, including evidence of sidewall slumping, delta foreset morphology, and long runout sediment flows from sidewall mass movement. These data were also used to examine lake floor morphology at the chosen drill sites and evaluate their suitability as drilling targets.

\subsection{Sediment distribution}

Whereas the central basin offers the greatest potential to recover the thickest/highest temporal resolution paleoclimate record, analysis of short cores from the deepest regions of the lake reveal a complex sequence of layers that include three primary sedimentary lithofacies: (1) 5-10 mm thick dark grey very fine sandy silt and light grey medium silt couplets; (2) 10-100 mm thick beds of dark grey fine sand that normally grade into grey medium silt; and (3) up to $1 \mathrm{~m}$ thick graded beds characterized by a medium to fine sand base, very fine sandy silt unit, and fine silt cap. The two thinner units likely formed during inflow events of different magnitudes, whereas the thick units formed during flows generated by mass-wasting on the basin margins, possibly following seismic events. This complex event stratigraphy precludes our ability to identify a clear annual signal - a key requirement for paleoclimate research objectives. In contrast, distinct summer-winter layers accumulate at the distal end of the lake and make the region the best target to resolve an annual stratigraphy (Roop et al., 2015a). These annual layers form in response to changes in sediment input and hydrodynamics through the year. Sediment trap data from MS-3 indicate that accumulation at the distal end of the lake generally ranges between 0.7 and $4.0 \mathrm{mg} \mathrm{cm}^{-2} \mathrm{day}^{-1}$ between November and May but drops below $0.5 \mathrm{mg} \mathrm{cm}^{-2}$ day $^{-1}$ between June and October. This seasonal variability in sediment dispersal and accumulation rate produces sedimentary couplets that reflect an annual cycle and make the distal end of the lake a primary target for an annually resolvable paleoclimate record.

\subsection{Environmental factors}

Environmental conditions also factored into site selection. Wind speeds up to $160 \mathrm{~km} \mathrm{~h}^{-1}$ have been recorded at the head of the lake and air flow can be consistently strong in spring and early summer. The prevailing northerly and northwesterly winds funnel down the $10 \mathrm{~km}$ length of the lake and can produce short-period $(\sim 4 \mathrm{~s})$ waves at least $2 \mathrm{~m}$ high. Drilling in these conditions is not possible. The south-eastern end of the lake is generally sheltered from these prevailing winds and wave heights are less than in the central basin, which meant that the south-eastern location was likely to provide calmer conditions for drilling.

\section{Drill system design}

Operating requirements for the $\mathrm{LOCH}$ project were unlike any encountered during previous scientific drilling activities in New Zealand. The project needed a drill system that could operate in deep water (at least $100 \mathrm{~m}$ ) and recover nearcontinuous high-quality core through a sequence of soft sediment (sand and mud) $\sim 80 \mathrm{~m}$ thick. Furthermore, wind and wave conditions at Lake Ohau can be extreme, so the ability to quickly mobilize the drilling system and move it to shelter in the event of high winds and rough water conditions, and relocate the rig above the site and re-enter the hole once conditions improved, was a key operation capability design requirement.

A fit-for-purpose drilling system was built in 2015 to meet $\mathrm{LOCH}$ project requirements, but the potential for deployment in a range of hard to access locations around the world has been considered in the design and build. Major components include a state-of-the-art barge; a riser system; soft sediment coring tools; and a drill rig. The initial barge concept was developed by Marine Surveyors (Mtech Ltd) and Webster Drilling and Exploration Ltd in collaboration with engineers at Victoria University of Wellington. The barge comprises two $11.8 \mathrm{~m}$ long pontoons that are constructed of a $6 \mathrm{~mm}$ steel plate and are connected by threaded Ishibek bars that run through steel transverse frames. It has an unloaded weight of $13 \mathrm{t}$ and can be disassembled for transport and fit into one standard $40 \mathrm{ft}$ long shipping container. A Webster Drilling HPP 600 rig was chosen for the LOCH operation. This rig is a through the head drive diamond coring rig capable of $13 \mathrm{t}$ pull-back, although the barge system in its current drilling operational configuration can only support a pullback of $8 \mathrm{t}$. The operational load included the rig and power pack $(4000 \mathrm{~kg}), 108 \mathrm{~m}$ of PWT casing $(2315 \mathrm{~kg}), 200 \mathrm{~m}$ of HWT drill string (3498 kg), and $600 \mathrm{~L}$ of fuel $(600 \mathrm{~kg})$, which provided the capability to complete the LOCH objectives. The system can support a larger load if a self-supporting riser is used, which would allow deployment of up to $400 \mathrm{~m}$ of PQ string and bring targets up to $400 \mathrm{~m}$ beneath the barge floor within reach.

A self-supporting riser was included in drill system design specifications to allow circulation of drilling mud to enhance core recovery and quality. A riser would also allow deployment of HWT drill string in "deep" water drilling environments and hole re-entry capability if required. An airbag system was designed to tension the riser and keep it separated from the barge so that, in the event of inclement weather, the platform and rig could be removed from the drill site, towed to sheltered anchorage, and subsequently repositioned over the riser once weather improved. If a disconnect was required, HWT drill string would be clamped above the slips and hung off the top of the PWT casing. Additional weight of the drill rod to the lake floor would be compensated for by increasing the buoyancy in the air bag. The four mooring 
lines would be tied off on the self-buoyant riser and the barge could then be towed off site.

\section{Field operations}

Drilling in winter, which is the calmest period, was considered impractical due to the short number of daylight hours ( $\sim 8.5$ per day in July vs. $\sim 13.5$ in February) and temperatures that frequently drop below $0{ }^{\circ} \mathrm{C}$. Environmental conditions in February-March are generally more settled than earlier in the summer. Wind speeds rarely exceed $60 \mathrm{~km} \mathrm{~h}^{-1}$ and typically range between 0 and $15 \mathrm{~km} \mathrm{~h}^{-1}$, and average day-night temperatures range from 8.5 to $24^{\circ} \mathrm{C}$. This period was selected for drilling to mitigate risks associated with adverse weather.

Primary access to the lake was via a gravel road that traverses the eastern margin of the lake (Fig. 1). A concrete boat ramp and jetty located at Port Bryson at the southeastern end of the lake are accessible from the road. The barge and drill system were delivered to the lake edge on two articulated trucks and lifted into position with a $30 \mathrm{t}$ crane. Barge assembly and rig fit-out was completed in $\sim 1 / 2$ day. An $11.09 \mathrm{~m}$ Seacraft alloy research vessel, the Beryl Brewin, was also delivered to Port Bryson on a tractor trailer unit and lifted into the lake with the crane. This vessel was used to manoeuvre the barge, deploy anchors, and serve as a support tender and core processing platform during drilling operations (Fig. 4). The barge was four-point-anchored to the lake bed using standard plough anchors and chain attached to $400 \mathrm{~m}$ of low stretch $12 \mathrm{~mm}$ Dyneema ${ }^{\circledR} 12$ strand braided rope. Anchor lines were tensioned off four hydraulic winches on the deck of the barge and powered off the rig's hydraulic power unit (Fig. 4). This system allows the rig to be repositioned to drill multiple offset holes without having to reset the anchors.

PWT casing $\left(139.7 \mathrm{~mm} \quad\left(5.5^{\prime \prime}\right)\right.$ external diameter/127.0 mm $\left(5.0^{\prime \prime}\right)$ internal diameter) was used as a riser and was deployed with the main rig winch. The riser was clamped with a bullring and slips installed below the barge deck and in front of the drill mast. A $1.3 \mathrm{~m}^{3}$ concrete block weighing $1.3 \mathrm{t}$ (in air) was connected to the bottom of the riser and used as a lake floor anchor. A $2 \mathrm{~m}$ long length of PWT casing with a flange at its top end was embedded in the concrete block to provide a "stinger" that extended $1 \mathrm{~m}$ into the sediment below the base of the block. Ports in the flange allowed wash-in cuttings to vent on top of the anchor block.

An airbag system comprising a $5 \mathrm{t}$ wrap around air bag was shackled to $203 \mathrm{~mm}\left(8^{\prime \prime}\right)$ internal diameter flanged pipe (Fig. 4) and was connected to the riser so that the top of the air bag sat $\sim 2.8 \mathrm{~m}$ below the lake water surface. Mooring lines were connected to four points at the bottom of the airbag pipe with blocks (and pulleys). However, once deployed, the drilling crew recognized that the top of the airbag system was mounted too close to the water surface and
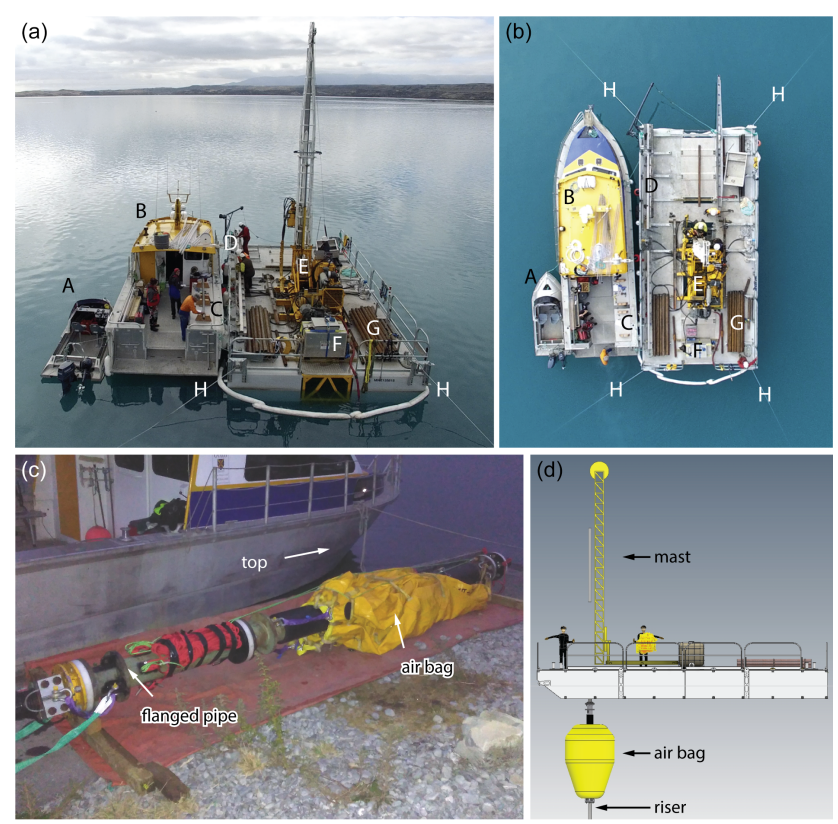

Figure 4: (a, b) - Photographs of the drill system deployed at Lake Ohau shown from stern view (note LGM terminal moraine in distance) and from above. A - alloy support vessel used to transport core to shore; B - RV Beryl Brewin; C - core curation area; D coring tool work area; E - Webster Drilling HPP 600 rig; F - double lined $350 \mathrm{~L}$ rig fuel tank; $\mathrm{G}$ - drill pipe; $\mathrm{H}$ - anchor lines. (c, d) - air bag attached to flanged pipe in pre-deployment configuration lying beside tender vessel; schematic diagram of barge and air bag in deployed configuration.

that the airbag volume/buoyancy was fluctuating in response to pressure changes caused by low-amplitude lake surface waves. The airbag system's automated pressure control was unable to maintain constant buoyancy during these shortperiod pressure changes, so the system was disconnected. Future deployments could include a riser buoyancy system that utilizes a light rigid shell cylindrical tank, instead of an inflatable air bag, which should mitigate buoyancy issues encountered during LOCH project operations. Drill crew members would control the volume of water or air in the tank to manage buoyancy and maintain a small positive air pressure in the tank to ensure it did not collapse. This system should be unaffected by variable pressure created by wave motion and the barge-riser disconnect capability could then be utilized if required.

A QD Tech, Inc wireline retrievable hydraulic piston corer (HPC) that recovers a $66.3 \mathrm{~mm}$ diameter core inside a plastic (Ocean Drilling Program; ODP) core liner was latched into the core barrel deployed in an HWT drill string $(114.3 \mathrm{~mm}$ $\left(4.5^{\prime \prime}\right)$ external diameter/101.6 $\mathrm{mm}\left(4^{\prime \prime}\right)$ internal diameter) within the PWT casing. Lake water was pumped into the drill string until a pressure of $4.14 \mathrm{MPa}(600 \mathrm{psi})$ was reached and shear pins holding the corer in place failed, allowing it to "fire" into the sediment. The sample tube could extend a 
Table 1. Drill site location data and core information.

\begin{tabular}{lllrrr}
\hline Site & Latitude & Longitude & Water depth $(\mathrm{m})$ & Number of core runs & Max. sediment depth (m) \\
\hline LOCH-1A & $44^{\circ} 16.844^{\prime} \mathrm{S}$ & $169^{\circ} 54.036^{\prime} \mathrm{E}$ & 101 & 20 & 60.2 \\
LOCH-1B & $44^{\circ} 16.872^{\prime} \mathrm{S}$ & $169^{\circ} 54.027^{\prime} \mathrm{E}$ & 101 & 29 & 82.3 \\
LOCH-2A & $44^{\circ} 16.789^{\prime} \mathrm{S}$ & $169^{\circ} 55.430^{\prime} \mathrm{E}$ & 68 & 14 & 43.0 \\
LOCH-2B & $44^{\circ} 16.790^{\prime} \mathrm{S}$ & $169^{\circ} 55.440^{\prime} \mathrm{E}$ & 68 & 14 & 43.6 \\
\hline
\end{tabular}

maximum $3 \mathrm{~m}$ ahead of the bit. An integrated bypass head was used to indicate when full stroke was achieved. The drill string was then pulled back $3 \mathrm{~m}$, lifting the sample tube out of the sediment and into the borehole. The entire inner assembly was then retrieved via wireline to the deck of the barge where the core tube was removed. While the HPC was being reset, the core barrel was advanced to the depth reached by the piston corer on its previous stroke. The HPC was redeployed and the process repeated. Each $3 \mathrm{~m}$ coring run took between 30 and $45 \mathrm{~min}$ and drilling operations were carried out around the clock.

Core liner containing recovered sediment was removed from the HPC and transferred to the tender (RV Beryl Brewin), where it was cut into two $1.5 \mathrm{~m}$ sections and capped. Sections that contained significant biogenic gas (methane) were perforated with a hand-held electric drill. Cores were left to rest for up to $10 \mathrm{~min}$, were placed in custom plywood boxes, and were transported to the jetty at Port Bryson onboard a $4.4 \mathrm{~m}$ alloy support vessel (Fig. 4). Shore-based staff collected the core from the jetty and drove it to a temporary field facility located above the control gate at the outlet to the Ohau canal (Fig. 1). The field facility included a refrigerated shipping container and portable office/lab. X-ray images of each core section were collected using a Ectotron portable system with a digital radiography plate. Images were used to examine core quality and results were reported via very highfrequency (VHF) radio to the tender vessel and passed to the head driller. Finally, core sections were placed into a storage rack system in the refrigerated shipping container.

The coring system performed exceptionally well and achieved near-complete sediment recovery in all four holes. Loss of up to $10 \mathrm{~cm}$ between coring runs occurred in each hole, but these gaps were covered via a two-hole offset coring at each site (Fig. 5). A splice for each site will be established using X-ray CT data. Recovery of diamicton at the base of the targeted sedimentary section was achieved at LOCH-1 and -2. Basic drill site information and coring outcomes are listed in Table 1. Full recovery of offset cores was achieved at LOCH-2. While we were unable to penetrate a stiff interval at $60 \mathrm{~m}$ below the lake floor in LOCH-1A, recovery of the full $80 \mathrm{~m}$ thick sedimentary sequence was achieved in LOCH-1B.

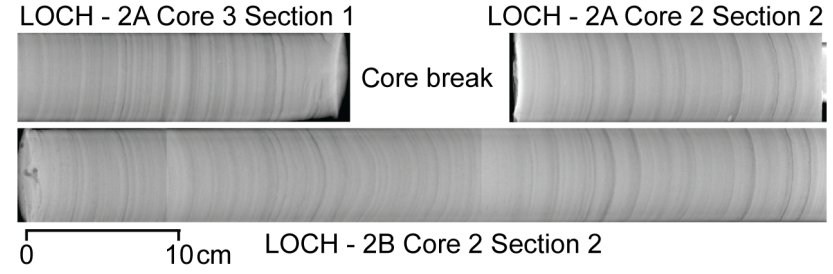

Figure 5. X-ray images showing $10 \mathrm{~cm}$ core loss at run break in LOCH-2A and recovery of the missing section in offset hole LOCH-2B (up to right). Distinct layers can be correlated between cores at $\mathrm{mm}$ scale from each site using visual and statistical techniques.

\section{Post drilling analysis and preliminary results}

\subsection{Non-destructive continuous measurements}

Core was transported in a refrigerated shipping container to a core facility located in the Geology Department at the University of Otago, Dunedin, New Zealand. Physical properties data including gamma-attenuation density, compressional (P)-wave velocity, and volume-specific magnetic susceptibility were collected on whole core using a Geotek multi-sensor core logger. X-ray computed tomography (Xray $\mathrm{CT}$ ) scans were obtained on whole cores at the Innervision Ltd CT facility at AgResearch, Mosgiel, New Zealand, using a GE Brightspeed medical X-ray CT scanner. We used these high-resolution data to establish a near-continuous ( $600 \mu \mathrm{m}$ resolution) density data series through regions of the core that were distorted due to biogenic gas bubbles. These data series are required to establish an annual layer count for the sedimentary record. Additional data including resistivity, high-resolution infinite volume magnetic susceptibility, colour spectrophotometry, and RGB line scan images were collected from the Geotek system once the cores were split. U-channel samples were then taken from one half and natural remanent magnetization intensity, inclination and relative declination and anhysteretic remanent magnetization were acquired every $1 \mathrm{~cm}$ using a $2 \mathrm{G}$ Enterprises superconducting rock magnetometer at the University of Otago. Continuous $\mu \mathrm{XRF}$ data are also being collected from the u-channels at $\mathrm{mm}$-scale resolution using an ITRAX housed at the Korea Polar Research Institute. 


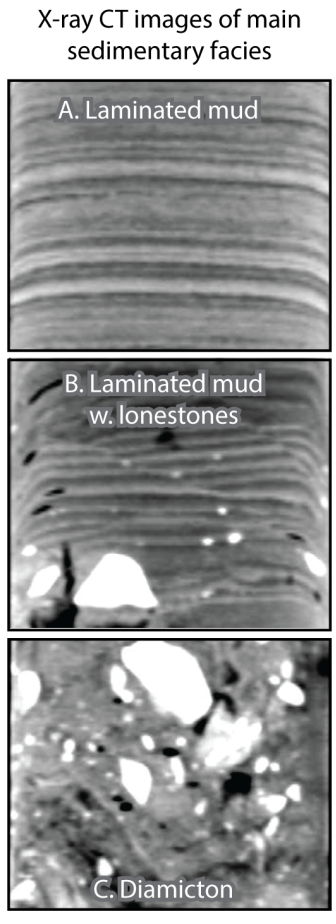

X-ray CT images of main
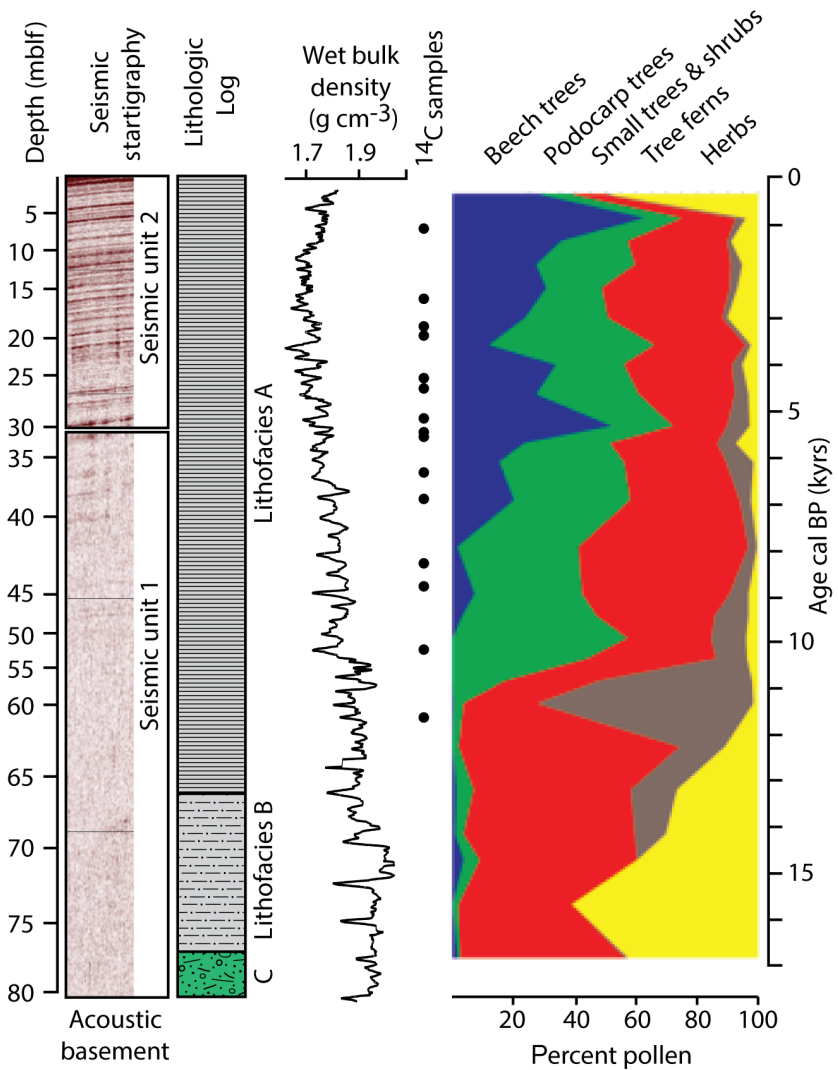

Figure 6. X-ray CT images of three primary facies recovered at LOCH-1 and -2. Seismic facies, basic stratigraphic column, and smoothed wet bulk density data from LOCH-1. Density minima every 1.5-3 m indicate core/section breaks. Pollen changes observed in core catcher samples from LOCH-1 showing a LGM to Holocene vegetation transition consistent with that observed at other sites in New Zealand. Preliminary ${ }^{14} \mathrm{C}$ samples (black dots) and associated age data align well with the age distribution inferred from pollen biostratigraphy.

\subsection{Sedimentology, stratigraphy, paleontology, and geochemistry}

Diamicton occurs at the base of the sedimentary sequences recovered at LOCH Sites 1 and 2 (Fig. 6) and likely represents subglacial or grounding zone proximal till deposited at the Last Glacial Maximum or during a phase of rapid retreat of the Ohau Valley glacier between 17900 and 17500 years ago (Putnam et al., 2013). Laminated sediments with occasional lone stones occur up to $4 \mathrm{~m}$ above the basal diamicton at LOCH Site 2 and $9 \mathrm{~m}$ at the LOCH Site 1 (Fig. 6). Laminated muds dominate the remaining sedimentary section at each site and offer potential for an unprecedented record of climate variability from the late glacial through the Holocene at decadal to annual resolution. Lithologic data from LOCH1 indicate that the transition between seismic units 1 (layered) and 2 (opaque) at $30 \mathrm{~m}$ below the lake floor does not coincide with a change in facies or significant environmental transition (Fig. 6). However, an increase in core disturbance due to biogenic gas escape occurs at and below this depth and suggests that the change in seismic character corresponds to the depth at which in situ biogenic activity, and related methane gas production, increase.
Preliminary micropaleontological analyses have been completed on core catcher material from both drill sites. The lowermost laminated sediments contain a typical late glacial pollen assemblage, which transitions up core through a typical New Zealand deglacial sequence (Fig. 6) (e.g. Vandergoes et al., 2008, 2013). Diatom concentration is very low at the base of the sedimentary sequence, but increases in the Holocene interval. Sixty-nine species from several genera, including Discostella, Cyclotella, Fragilaria, Achnanthidium, and Lindavia, have been identified so far. Twentysix radiocarbon dates have been generated from terrestrial and aquatic macrofossils and indicate ages that are consistent with our preliminary pollen biostratigraphy and layer counts (Fig. 6).

\subsection{Future work}

A core workshop was held at GNS Science on October 2016 and analysis of data continues today. Our team is developing plans to establish a latitudinal transect along New Zealand to core several lake systems in the North and northern South islands to examine environmental response to changes in the position of the westerlies and the impact on rainfall 
distribution. A major goal is to integrate these new highresolution datasets from New Zealand with ice core and sediment records from the south-western Pacific and Ross Sea sectors of Antarctica (e.g. Bertler et al., 2018; Escutia et al., 2003) to reveal details regarding climate system evolution in the Southern Hemisphere as Earth's surface temperatures increased over the past 20000 years.

Data availability. Preliminary data outlined in this progress report are not publicly available as they are still being evaluated by the LOCH project team. Fully vetted datasets from the LOCH cores will be made available when scientific papers and reports are published.

Author contributions. RL, GD, and MV lead the LOCH project and are involved in all aspects from lake monitoring to sediment core analysis. All authors contributed to the design and implementation of various aspects of the field operation and/or data acquisition phase. RL, AP, and TK wrote the original version of this paper, which was refined by GD, MV, JH, and AF. AG and PU designed and ran the high-resolution seismic survey. JH and SF conducted chirp surveys and collected Mackereth cores. JH and MV acquired $\mathrm{X}$-ray CT data. AF and RC conducted the bathymetric survey and acquired and interpreted acoustic Doppler current profile data with GS. HR analysed short cores and monitoring data as part of her $\mathrm{PhD}$ project. SW contributed to the lake monitoring programme and helped acquire lake column turbidity data. BD was head curator and acquired physical property data. ML acquired preliminary $\mu \mathrm{XRF}$ data. FN, PL, GW, and FF conducted paleomagnetic analysis. LC acquired diatom data. XL conducted palynological analysis. TK and AP led the drilling operation and GB, MC, MH, EK, SL, DM, CM, PM, PD, CR, PR, DS, and MT were members of the drilling and/or drill site management team.

Competing interests. The authors declare that they have no conflict of interest.

Acknowledgements. This research was supported by public research funding from the Government of New Zealand via contract C05X1702 to GNS Science and a Marsden Fund award GNS1302, and by the Italian Project of Strategic Interest NextData PNR 2011-2013. This is PMEL contribution number 4770. We are grateful to the communities of Twizel and McKenzie Basin, Mark Allen, Chris Lynch and staff at Meridian Energy Ltd, Chris and Ray Spiers, the team at Radiographic Supplies, Liko and Simon Inkersell (Lake Ohau Station), and Dean Madden (New Zealand Inland Coastguard). We also thank the three reviewers who helped improve this paper with their comments and suggestions.

Edited by: Ulrich Harms

Reviewed by: Julie Brigham-Grette, Frank Rack, and one anonymous referee

\section{References}

Barnes, E. A. and Polvani, L.: Response of the Midlatitude Jets, and of Their Variability, to Increased Greenhouse Gases in the CMIP5 Models, J. Climate, 26, 7117-7135, https://doi.org/10.1175/jcli-d-12-00536.1, 2013.

Barrell, D., Anderson, B., and Denton, G.: Glacial geomorphology of the central South Island, New Zealand, GNS Science, GNS Science monograph 27 , p. $81+$ map ( 5 sheets $)+$ legend (1 sheet), 2011.

Bertler, N. A. N., Conway, H., Dahl-Jensen, D., Emanuelsson, D. B., Winstrup, M., Vallelonga, P. T., Lee, J. E., Brook, E. J., Severinghaus, J. P., Fudge, T. J., Keller, E. D., Baisden, W. T., Hindmarsh, R. C. A., Neff, P. D., Blunier, T., Edwards, R., Mayewski, P. A., Kipfstuhl, S., Buizert, C., Canessa, S., Dadic, R., Kjær, H. A., Kurbatov, A., Zhang, D., Waddington, E. D., Baccolo, G., Beers, T., Brightley, H. J., Carter, L., Clemens-Sewall, D., Ciobanu, V. G., Delmonte, B., Eling, L., Ellis, A., Ganesh, S., Golledge, N. R., Haines, S., Handley, M., Hawley, R. L., Hogan, C. M., Johnson, K. M., Korotkikh, E., Lowry, D. P., Mandeno, D., McKay, R. M., Menking, J. A., Naish, T. R., Noerling, C., Ollive, A., Orsi, A., Proemse, B. C., Pyne, A. R., Pyne, R. L., Renwick, J., Scherer, R. P., Semper, S., Simonsen, M., Sneed, S. B., Steig, E. J., Tuohy, A., Venugopal, A. U., Valero-Delgado, F., Venkatesh, J., Wang, F., Wang, S., Winski, D. A., Winton, V. H. L., Whiteford, A., Xiao, C., Yang, J., and Zhang, X.: The Ross Sea Dipole - temperature, snow accumulation and sea ice variability in the Ross Sea region, Antarctica, over the past 2700 years, Clim. Past, 14, 193-214, https://doi.org/10.5194/cp-14193-2018, 2018.

Chang, E. K. M., Guo, Y., and Xia, X.: CMIP5 multimodel ensemble projection of storm track change under global warming, J. Geophys. Res.-Atmos., 117, D23118, https://doi.org/10.1029/2012JD018578, 2012.

Cossu, R., Forrest, A. L., Roop, H. A., Dunbar, G. B., Vandergoes, M. J., Levy, R. H., Stumpner, P., and Schladow, S. G.: Seasonal variability in turbidity currents in Lake Ohau, New Zealand, and their influence on sedimentation, Mar. Freshwater Res., 67, 1725-1739, https://doi.org/10.1071/MF15043, 2016.

Escutia, C., Warnke, D., Acton, G. D., Barcena, A., Burckle, L., Canals, M., and Frazee, C. S.: Sediment distribution and sedimentary processes across the Antarctic Wilkes Land margin during the Quaternary, Deep-Sea Res. Pt. II, 50, 1481-1508, https://doi.org/10.1016/S0967-0645(03)00073-0, 2003.

Folland, C. K., Renwick, J. A., Salinger, M. J., and Mullan, A. B.: Relative influences of the Interdecadal Pacific Oscillation and ENSO on the South Pacific Convergence Zone, Geophys. Res. Lett., 29, 21-24, https://doi.org/10.1029/2001GL014201, 2002.

Garreaud, R. D.: Precipitation and Circulation Covariability in the Extratropics, J. Climate, 20, 4789-4797, 2007.

Golledge, N. R., Mackintosh, A. N., Anderson, B. M., Buckley, K. M., Doughty, A. M., Barrell, D. J. A., Denton, G. H., Vandergoes, M. J., Andersen, B. G., and Schaefer, J. M.: Last Glacial Maximum climate in New Zealand inferred from a modelled Southern Alps icefield, Quaternary Sci. Rev., 46, 30-45, https://doi.org/10.1016/j.quascirev.2012.05.004, 2012.

Irwin, J.: Bottom sediments of Lake Tekapo compared with adjacent Lakes Pukaki and Ohau, South Island, New Zealand, N.Z., Journal of Marine and Freshwater Research, 12, 245-250, 1978. 
Lim, E.-P., Hendon, H. H., Arblaster, J. M., Delage, F., Nguyen, H., Min, S.-K., and Wheeler, M. C.: The impact of the Southern Annular Mode on future changes in Southern Hemisphere rainfall, Geophys. Res. Lett., 43, 7160-7167, https://doi.org/10.1002/2016GL069453, 2016.

Mackereth, F. J. H.: A Portable Core Sampler for Lake Deposits, Limnol. Oceanogr., 3, 181-191, https://doi.org/10.4319/lo.1958.3.2.0181, 1958.

Putnam, A. E., Denton, G., Schaefer, J. M., Broecher, W. S., Quesada, P., Ladig, K., Doughty, A., Kelley, S., Kaplan, M., Andersen, B., Barrell, D., Alley, R., Putnam, D., Evenson, E., Finkel, R., and Schwartz, R.: Timing of the last mountain-glacier maximum at middle latitudes north and south, Absract; XVIII INQUA Congeress, July 2011, Bern Switzerland, 2011.

Putnam, A. E., Schaefer, J. M., Denton, G. H., Barrell, D. J. A., Birkel, S. D., Andersen, B. G., Kaplan, M. R., Finkel, R. C., Schwartz, R., and Doughty, A. M.: The Last Glacial Maximum at $44^{\circ} \mathrm{S}$ documented by a ${ }^{10} \mathrm{Be}$ moraine chronology at Lake Ohau, Southern Alps of New Zealand, Quaternary Sci. Rev., 62, 114141, https://doi.org/10.1016/j.quascirev.2012.10.034, 2013.

Roop, H., Levy, R., Dunbar, G., Vandergoes, M., Howarth, J., Fitzsimons, S., Moon, H., Zammit, C., Ditchburn, R., Baisden, T., and Yoon, H.: A hydroclimate-proxy model based on sedimentary facies in an annually laminated sequence from Lake Ohau, South Island, New Zealand, J. Paleolimnol., 55, 1-16, https://doi.org/10.1007/s10933-015-9853-3, 2015a.

Roop, H. A., Dunbar, G. B., Levy, R., Vandergoes, M. J., Forrest, A. L., Walker, S. L., Purdie, J., Upton, P., and Whinney, J.: Seasonal controls on sediment transport and deposition in Lake Ohau, South Island, New Zealand: Implications for a highresolution Holocene palaeoclimate reconstruction, Sedimentology, 62, 826-844, https://doi.org/10.1111/sed.12162, 2015b.

Salinger, M. J., Renwick, J. A., and Mullan, A. B.: Interdecadal Pacific Oscillation and South Pacific climate, Int. J. Climatol., 21, 1705-1721, https://doi.org/10.1002/joc.691, 2001.

Schaefer, J. M., Denton, G. H., Barrell, D. J. A., Ivy-Ochs, S., Kubik, P. W., Andersen, B. G., Phillips, F. M., Lowell, T. V., and Schlüchter, C.: Near-Synchronous Interhemispheric Termination of the Last Glacial Maximum in Mid-Latitudes, Science, 312, 1510-1513, https://doi.org/10.1126/science.1122872, 2006.

Shindell, D. T. and Schmidt, G. A.: Southern Hemisphere climate response to ozone changes and greenhouse gas increases, Geophys. Res. Lett., 31, L18209, https://doi.org/10.1029/2004gl020724, 2004.
Thompson, D. W. J. and Solomon, S.: Interpretation of Recent Southern Hemisphere Climate Change, Science, 296, 895-899, https://doi.org/10.1126/science.1069270, 2002.

Toggweiler, J. R. and Russell, J.: Ocean circulation in a warming climate, Nature, 451, 286-288, 2008.

Ummenhofer, C. C. and England, M. H.: Interannual Extremes in New Zealand Precipitation Linked to Modes of Southern Hemisphere Climate Variability, J. Climate, 20, 5418-5440, https://doi.org/10.1175/2007jcli1430.1, 2007.

Ummenhofer, C. C., Sen Gupta, A., and England, M. H.: Causes of Late Twentieth-Century Trends in New Zealand Precipitation, J. Climate, 22, 3-19, https://doi.org/10.1175/2008jcli2323.1, 2009.

Vandergoes, M. J., Dieffenbacher-Krall, A. C., Newnham, R. M., Denton, G. H., and Blaauw, M.: Cooling and changing seasonality in the Southern Alps, New Zealand during the Antarctic Cold Reversal, Quaternary Sci. Rev., 27, 589-601, https://doi.org/10.1016/j.quascirev.2007.11.015, 2008.

Vandergoes, M. J., Newnham, R. M., Denton, G. H., Blaauw, M., and Barrell, D. J. A.: The anatomy of Last Glacial Maximum climate variations in south Westland, New Zealand, derived from pollen records, Quaternary Sci. Rev., 74, 215-229, https://doi.org/10.1016/j.quascirev.2013.04.015, 2013.

Vandergoes, M., Howarth, J., Dunbar, G., Turnbull, J., Roop, H., Levy, R., Li, X., Prior, C., Norris, M., Keller, L., Baisden, T., Ditchburn, B., and Fitzsimons, S.: Integrating chronological uncertainties for annually laminated lake sediments using layercounting, independent chronologies and Bayesian age modelling (Lake Ohau, South Island, New Zealand), Quaternary Sci. Rev., in press, https://doi.org/10.1016/j.quascirev.2018.03.015, 2018.

Wang, G. and Cai, W.: Climate-change impact on the 20thcentury relationship between the Southern Annular Mode and global mean temperature, Sci. Rep.-UK, 3, 2039, https://doi.org/10.1038/srep02039, http://www.nature.com/ articles/srep02039\#supplementary-information, 2013.

Woods, R., Hendricks, J., Henderson, R., and Tait, A.: Estimating mean flow of New Zealand rivers, J. Hydrol. NZ, 45, 95-109, 2006. 